\title{
PENGGUNAAN GEN PENYANDI TUMBUH CEPAT DALAM PRODUKSI BENIH UDANG WINDU Penaeus monodon
}

\author{
Haryanti, Ketut Mahardika, Fachrudin, Ida Komang Wardana, \\ I Gusti Ngurah Permana, dan Sari Budi Moria Sembiring \\ Balai Besar Penelitian dan Pengembangan Budidaya Laut \\ Jl. Br. Gondol Kec. Gerokgak Kab. Buleleng, Kotak Pos 140, Singaraja-Bali 81101 \\ E-mail: haryanti@indosat.net.id
}

(Naskah diterima: 12 September 2012; Disetujui publikasi: 11 Oktober 2012)

\begin{abstract}
ABSTRAK
Dalam upaya mengembalikan kesuksesan produksi udang windu $P$. monodon maka langkah perbaikan dan antisipasi mengatasi kegagalan terus dilakukan. Di antara kegagalan yang terjadi adalah penurunan sifat genetik. Penelitian ini bertujuan untuk mengaplikasikan gen penyandi tumbuh cepat pada benih udang windu yang diproduksi melalui pembenihan. Pembenihan menggunakan sistem yang mengaplikasikan biosecurity, probiotik, pakan alami, dan buatan. Ada 35 populasi benih F-1 (PL 12-15) yang dapat diproduksi dengan jumlah yang bervariasi. Gen penyandi tumbuh cepat yang telah diperoleh pada locus PmMS-11A dari mikrosatelit/SSRs (Simple Sequence Repeats), selanjutnya digunakan sebagai indikator tumbuh cepat pada benih-benih yang diproduksi melalui amplifikasi PCR dan dikonfirmasi dengan metode SSCP (Single Strand Confirmation Polyacrilamide). Hasil yang diperoleh menunjukkan bahwa gen penyandi tumbuh cepat dapat ditunjukkan oleh locus PmMS11-A pada benih udang windu. Tingkat keakuratan gen penyandi tumbuh cepat tersebut pada benih udang windu turunan F-1 terekspresi pada allel 144 bp. Hal ini juga ditunjukkan keakurasian prediksi dari karakter fenotipnya setelah budidaya di tambak. Produk benih yang dihasilkan sebanyak 838.021 ekor (tumbuh cepat) dan kontrol 172.526 ekor.
\end{abstract}

KATA KUNCI: produksi, marker gen, tumbuh cepat, $P$. monodon

ABSTRACT: Fry production of black tiger shrimp Penaeus monodon with applied of gene marker for fast growth trait. By: Haryanti, Ketut Mahardika, Fachrudin, Ida Komang Wardana, I Gusti Ngurah Permana, and Sari Budi Moria Sembiring

In an effort to recover the success of black tiger, P. monodon shrimp production, improvement, and the anticipated of failure culture continues was done. Among the failures was caused by decreasing of genetic traits. Present study was to apply of gene marker for fast growing to shrimp fry produced through fry production. Fry production was conducted with common system, such as by applying biosecurity, probiotic, natural, and artificial feed. There were thirty five shrimp fries (F-1) population on PL 12-15 stage that can produce with various amounts. To applied fast growth gene marker of PMMS-1 1 A from microsatellite (Simple Sequence Repeats/SSRs), the method of analysis used in the PCR amplification and confirm zed with SSCP method on shrimp fries. The results showed that gene marker correspond on fast growth trait could identified by using locus PmMS-1 1 A on DNA fragment of 144 bp. The accurate level of gene marker to fast growth trait on fry will prove after culture at pond with 
phenotypic prediction. The production of shrimp fries using microsatellite locus PmMS$11 \mathrm{~A}$ on fast growth was of 838.021 shrimp fries and as control was 172.526 shrimp fries.

\section{KEYWORDS: production, gene marker, fast growth, P. monodon}

\section{PENDAHULUAN}

Perikanan budidaya di Indonesia terus meningkat secara signifikan. Khusus pada budidaya udang yang merupakan kegiatan akuakultur terbesar di Indonesia dengan produksi 350.000 ton/tahun, menduduki urutan keempat setelah Cina (900.000 ton/ tahun), Thailand (500.000 ton/tahun), dan Vietnam (400.000 ton/tahun) (Ditjen Perikanan Budidaya, 2009). Udang $P$. monodon merupakan spesies budidaya domestik yang mendominasi produksi udang nasional pada tahun 1990. Pada awalnya budidaya udang windu cepat berkembang dengan ukuran besar, cepat tumbuh, dan mempunyai sintasan yang tinggi. Namun, mulai awal tahun 2000 produksi udang windu menurun karena kegagalan budidaya oleh infeksi penyakit WSSV (White Spot Syndrome Virus), sehingga mengakibatkan volume ekspor udang tersebut juga mengalami penurunan sangat tajam.

Dalam upaya mengembalikan kesuksesan budidaya udang windu, $P$. monodon maka langkah perbaikan dan antisipasi serta pencegahan terhadap faktor kegagalan terus dilakukan. Satu di antara upaya yang mendapatkan perhatian adalah penanganan terhadap karakter genetik udang windu. Walaupun program selektif breeding $P$. monodon melalui induk alam sudah banyak dilakukan, namun terbukti pada udang tersebut sulit untuk didomestikasi (Wilson et al., 2002). Hal ini terlihat dari dominasi produksi global $>450.000$ ton/tahun, namun kurang dari $1 \%$ merupakan produksi dari induk yang terdomestikasi (Rosenberry, 2000). Dengan demikian program peningkatan genetik secara komersial belum diimplementasikan secara ekonomis pada udang windu.

Perbaikan genetik melalui seleksi pada induk $P$. monodon yang berasal dari alam akan berpengaruh terhadap populasi yang dihasilkan. Dalam seleksi, performansi induk yang dihasilkan cenderung menunjukkan diversitas genetik yang berkurang bila dibandingkan dengan induk alam. Pada udang introduksi L. vannamei, yang merupakan hasil seleksi breeding, jelas terjadi penurunan diversity genetik, dan secara keseluruhan menyebabkan fitness yang rendah pada populasi yang ada. Jika dalam jumlah besar udang tersebut terlepas dari lingkungan budidaya, akibat lanjut adalah terjadinya pengaruh komposisi genetik pada populasi alam yang berbeda atau interbreeding antar spesies udang (Xu et al., 2001).

Dewasa ini, pengembangan udang windu tumbuh cepat menjadi sangat menarik untuk diuji, mengingat baik dalam seleksi atau produksi pada budidaya, karakter tersebut akan menguntungkan. Evaluasi gen pengontrol tumbuh cepat dapat dieksplor dari performansi susunan gen dari udang melalui analisis molekuler genetik (mikrosalelit). Dengan demikian, nampaknya skala prioritas dalam pembenihan untuk target keberhasilan budidaya adalah perbaikan mutu benih udang windu. Benih yang dihasilkan dari induk udang windu diharapkan akan menghasilkan kualitas benih yang baik secara genotip maupun fenotip.

Dewasa ini, banyak kegiatan produksi benih dan induk udang telah difokuskan melalui teknik seleksi dengan mengedepankan sifat-sifat yang menguntungkan bagi budidaya (tumbuh cepat, toleran-resisten terhadap infeksi virus, sintasan, reproduksi, dan lain-lain). Penggunaan penciri gen untuk karakter tersebut di atas dalam produksi atau seleksi (Marker Assisted Selection/MAS) akan sangat bermanfaat bagi peningkatan dan keberhasilan budidaya udang windu. MAS merupakan alat baru dalam breeding yang menggunakan marker molekuler atau genetik marker untuk menyeleksi sifat yang diinginkan.

Dari beberapa hasil uji pendahuluan yang telah diperoleh dalam breeding pada udang windu yang bersifat SPF dengan pendeteksian terhadap 8 jenis infeksi virus (WSSV/White Spot Syndrome Virus, IHHNV/Infectious Hypodermal and Haematopoietic Necrosis Virus; TSV/Taura Syndrom Virus; IMNV/Infectious Myonecrosis Virus; NHPB/Necrotizing Hepato Pancreatisis Bacteria; HPV/Hepatopancreatic 
Parvovirus; YHV/GAV/Yellow Head Virus/Gill Associated Virus; MBV/Monodon Baculo Baculo Virus), nampak bahwa benih udang turunan F-1 yang bersifat SPF dengan metode pemeliharaan yang mengaplikasikan biosecurity sebesar 85\%-90\%. Sementara, untuk induk udang windu yang berasal dari alam, sifat SPF tersebut menunjukkan angka yang relatif lebih kecil (60\%-70\%) (Haryanti et al., 2006). $\mathrm{Hal}$ ini karena adanya infeksi virus selama penampungan di tempat pengumpul dan banyaknya kegiatan budidaya tambak yang ada di sepanjang garis pantai.

Dalam produksi benih udang windu dengan menggunakan seleksi menjadi penting untuk mengetahui besaran korelasi genetik antara sifat-sifat yang diinginkan dalam rangka mengoptimalkan kerja seleksi dan mengontrol respons korelasi (Gitterle et al., 2005a). Pada L. vannamei, korelasi genetik antara sifat resisten terhadap TSV dan pertumbuhan tidak memberikan dampak yang menguntungkan (Fjalestad et al., 1999; Argue et al., 2002). Namun, menurut Gitterle et al. (2005b), melaporkan bahwa ada keuntungan korelasi genetik antara laju pertumbuhan dan sintasan udang di tambak.

Balai Besar Penelitian dan Pengembangan Perikanan Budidaya Laut Gondol, Bali telah melakukan penelitian seleksi breeding udang windu dari turunan alam ( $\mathrm{F}-0$ ) dan generasi pertama (F-1) yang terarah dan sistematik. Hasil seleksi breeding udang windu dari turunan alam (F-0) yang berasal dari perairan Timika dan Aceh serta generasi pertama (F-1), secara fenotip mempunyai laju pertumbuhan sangat bervariasi. Dari hasil penelitian Benzie et.al. (1997), terbukti bahwa faktor genetik sangat berpengaruh pada kualitas larva $P$. monodon, sementara pertumbuhan dikontrol oleh faktor genetik. Oleh karena itu, peranan faktor genetik dalam breeding sangat penting untuk memperoleh induk dan benih yang unggul. Hal ini ditunjukkan oleh hubungan yang erat antara penurunan produktivitas induk dengan variabilitas pertumbuhan. Dari pengembangan penyandi gen untuk seleksi udang $P$. monodon telah diperoleh locus Pm MS-11 A sebagai locus kuantitatif untuk allel gen tumbuh cepat dengan berat molekul $144 \mathrm{bp}$.

Penelitian produksi benih dengan menyeleksi karakter gen tumbuh cepat menggunakan penyandi gen menjadi pilihan mendesak untuk mendapatkan benih udang windu dengan sifat fenotip dan genotip yang lebih baik. Dari keberhasilan upaya tersebut diharapkan dapat memotivasi praktisi untuk menggunakan udang windu sebagai spesies andalan dalam bisnis budidaya perikanan. Dampak lanjut adalah memberikan peluang industri hatcheri skala komersial untuk memasok kebutuhan benih pada budidaya tambak sehingga ke depan keberhasilan budidaya akan mengembalikan citra Indonesia sebagai penghasil udang windu terbesar di dunia.

\section{BAHAN DAN METODE}

\section{Pembenihan Udang Windu $P$. monodon}

Dalam pembenihan udang windu, beberapa tahapan harus dilakukan sesuai dengan standar operasional yang telah ada, sehingga menghasilkan benih berkualitas. Managemen induk merupakan tahapan yang penting. Sebelum induk udang dipijahkan, performansi induk harus mengikuti kondisi SPF (Spesific Pathogen Free), yaitu diuji ada tidaknya infeksi virus TSV, WSSV, IHHNV, YHV, BP, MBV, HPV, NHPB, dan IMNV. Pengujian menggunakan spesifik primer (Forward dan Reverse) dan diamplifikasi dengan Speedy PCR. Dari hasil pengujian, induk udang windu harus bersifat negatif terhadap semua infeksi jenis virus.

Produksi benih udang windu dalam penelitian diperoleh melalui 2 kali pembenihan. Induk-induk udang windu diaklimatisasi sebelum dilakukan rangsangan pematangan gonad melalui ablasi tangkai mata. Pemijahan akan terjadi setelah 2-3 hari ablasi. Telur yang dihasilkan selanjutnya diinkubasi hingga menetas menjadi larva stadia awal (nauplii). Larva udang windu turunan F-1 dipelihara secara famili untuk memudahkan dalam aplikasi penyandian gen tumbuh cepat.

Pemeliharaan larva dengan memberikan pakan berupa Chaetoceros ceratosporum, Skeletonema sp., Artemia sp., dan pakan buatan mikroencapsulasi. Kepadatan awal $C$. ceratosporum pada stadia awal larva sebanyak 5.000-20.000 sel/mL sedangkan pada stadia lanjut diberikan Skeletonema sp. (25.000$35.000 \mathrm{sel} / \mathrm{mL}$ ) dan Artemia sp. (5-1 5 naupli/ larva). Pergantian air dimulai saat stadia zoea3 hingga stadia post larva dengan tingkat yang berbeda (15\%-50\%). Larva udang dipelihara hingga stadia post larva (PL 12-15). Setiap melakukan tahapan-tahapan tersebut di atas, penerapan metode biosecurity menjadi bagian utama untuk mengkondisikan sarana dan 
prasarana hatcheri dalam situasi bersih, yaitu melalui sterilisasi peralatan, penggunaan air melalui ultra membran filter, kebersihan teknisi, dan lain-lain.

Selama produksi benih udang windu, digunakan probiotik Alteromonas sp. BY-9 dan Bacillus sp. BC dengan kepadatan $10^{5} \mathrm{CFU} /$ $\mathrm{mL}$ atau setara dengan $0,5 \mathrm{~L} / \mathrm{m}^{3}$. Kultur massal probiotik disiapkan secara aseptik dengan volume $20 \mathrm{~L}$ dan diinkubasi selama 48 jam. Pemberian probiotik setiap hari hingga larva pada stadia PL-12. Pengamatan dilakukan terhadap daya tetas telur, frekuensi pemijahan, sintasan, dan deteksi virus dengan PCR diamati pada PL-1 dan PL-12.

\section{Penggunaan Gen Penyandi Tumbuh Cepat Pada Benih Udang Windu F-1}

Gen penyandi tumbuh cepat yang telah diperoleh melalui metode Mikrosatelit/SSR/ Simple Sequence Repeats) (Haryanti et al., 2012), digunakan untuk seleksi populasi benih udang windu yang diproduksi dari pembenihan. Gen penyandi tersebut sebagai indikator pada benih F-1 dengan mengekspresikan gen tumbuh cepat. Konfirmasi keberadaan gen tumbuh cepat pada induk udang windu jantan dan betina juga dianalisis. Aplikasi gen penyandi tumbuh cepat pada locus PmMS-11 A diawali dengan amplifikasi PCR pada target region $144 \mathrm{bp}$. Separasi amplikon menggunakan elektroforesis. Separasi elektroforesis selain menggunakan $2 \%$ agarose, juga dengan metode SSCP (Single Strand Confirmation Polymorphisme).

Dalam penelitian ini, ekstraksi DNA benih F-1 (PL-12-15) dilakukan pada 35 populasi (2 kali pembenihan) menggunakan kit QIAmp DNA mini kit (Qiagen 51304). Sementara, ekstraksi DNA untuk induk jantan dan betina masing-masing sebanyak 20 ekor. Genom DNA selanjutnya diamplifikasi dengan Speedy PCR. Reagen amplifikasi (Go Taq Polymerase kit) Promega) terdiri atas $10 x$ buffer, $10 \mathrm{mM}$ dNTP, 100 mM primer Pm MS-11 A (F) dan (R), 25 mM $\mathrm{MgCl} 2$ dan taq polimerase. Thermal cycle untuk amplifikasi digunakan suhu denaturasi awal $95^{\circ} \mathrm{C}$ selama 120 detik ( 1 siklus). Siklus berikutnya adalah sebanyak 40 kali dengan suhu denaturasi $95^{\circ} \mathrm{C}$ ( 10 detik), suhu annealing $60^{\circ} \mathrm{C}$ (10 detik) dan suhu ekstensi $72^{\circ} \mathrm{C}$ (20 detik). Amplifikasi PCR diakhiri dengan ekstensi akhir pada suhu $37^{\circ} \mathrm{C}$ selama 3 menit. Amplicon yang diperoleh selanjutnya diseparasi dengan menggunakan agarose $2 \%$ (0,5 x SB buffer) dan polyacrilamid serta silver staining (metode SSCP) (Gene Gel Excel 12.5/24).

Hasil separasi yang menunjukkan ekspresi gen tumbuh cepat (pita gen $144 \mathrm{bp}$ ) selanjutnya digunakan untuk menentukan bahwa populasi benih F-1 dengan famili yang sama diprediksi nantinya akan tumbuh cepat setelah dipelihara di tambak, sedangkan yang tidak mempunyai gen tumbuh cepat dijadikan kontrol.

\section{HASIL DAN BAHASAN}

\section{Produksi Benih Udang Windu P. monodon}

Hasil pengamatan terhadap ukuran induk udang ( $\mathrm{F}-0$ ) yang digunakan terlihat bahwa induk udang betina dan jantan sesuai dengan kriteria kelayakan ukuran induk yang akan digunakan untuk pembenihan (Tabel 1). Dari 2 kali pembenihan digunakan induk udang masing-masing 40 dan 20 pasang, relatif sehat pada saat diaklimatisasi dengan penambahan oksigen murni/cair. Hal ini dilakukan untuk

Tabel 1. Ukuran panjang dan bobot induk udang windu, $P$. monodon yang digunakan untuk pembenihan

Table 1. Size of body length and weight of black tiger shrimp, $\boldsymbol{P}$. monodon broodstock used for breeding

\begin{tabular}{lcc}
\hline $\begin{array}{c}\text { Induk } \\
\text { Broodst ock }\end{array}$ & $\begin{array}{c}\text { Panjang } \\
\text { Body length } \mathbf{( c m )}\end{array}$ & $\begin{array}{c}\text { Bobot } \\
\text { Body weight } \mathbf{( g )}\end{array}$ \\
\hline Jantan (Male) I & $18.2-22.1$ & $52.1-94.0$ \\
Jantan (Male) II & $21.7-23.0$ & $68.1-83.8$ \\
Betina (Female) I & $26.4-28.1$ & $145.8-197.8$ \\
Betina (Female) II & $25.0-28.0$ & $146.1-186.0$ \\
\hline
\end{tabular}


memulihkan kondisi kesehatan udang setelah proses pengangkutan. Selama aklimatisasi, induk juga didesinfeksi untuk menghilangkan kontaminan/bakteri yang melekat pada tubuh induk. Pakan segar yang telah didesinfeksi dengan iodine $100 \mathrm{mg} / \mathrm{L}$ (cumi, kerang, cacing laut, hati sapi) diberikan sebanyak $15 \%$ bobot masa/hari dengan frekuensi 2 kali/hari. Bila respons pakan sudah menunjukkan positif, maka dilakukan pengujian sifat SPF terhadap 7 jenis infeksi virus. Induk udang yang tidak terinfeksi virus selanjutnya dipindahkan ke dalam bak induk untuk dilakukan ablasi/ pemotongan tangkai mata.

Hasil dari deteksi keberadaan virus dalam induk jantan dan betina udang windu disajikan pada Tabel 2. Terlihat bahwa induk udang betina tidak terinfeksi virus yang direkomendasikan untuk sifat SPF (Spesific Pathogen Free). Adanya Infeksi virus dapat berasal dari perairan asal induk, mengingat sudah meluasnya sebaran virus akibat aktivitas budidaya udang.

Pengujian untuk mendeteksi infeksi virus digunakan spesifik primer yang didesain untuk jenis virus pada udang windu dari Indonesia. Target region untuk mengamplifikasi fragment DNA IHHNV adalah 77 bp dan 80 bp, sedangkan MBV 135 bp. Pada infeksi virus WSSV diperoleh target region $69 \mathrm{bp}, 93 \mathrm{bp}$, $113 \mathrm{bp}$, dan $154 \mathrm{bp}$. Pada infeksi TSV, target region spesifik adalah 213 bp. Penggunaan primer dengan target fragment DNA pendek tersebut akan meningkatkan sensitivitas dalam deteksi, sehingga tingkat awal infeksi virus dengan jumlah virion yang masih rendah dapat diketahui secara dini.

Hasil pengamatan terhadap pemijahan yang diindikasikan dari daya tetas telur induk udang windu, diperoleh hasil seperti pada Tabel 3. Dari Tabel 3 terlihat bahwa daya tetas telur sangat bervariasi, baik untuk peneluran pertama hingga kelima. Daya tetas tertinggi sebesar 100\% (pembenihan I) dan 90,5\% (pembenihan II). Pada pembenihan pertama, hampir semua induk udang betina memijah (36 ekor), walaupun ada 5 ekor yang tidak menetas $(0 \%)$ dan 8 ekor dengan daya tetas sangat rendah $(1,2 \%-38,8 \%)$. Pada pemijahan kedua, jumlah induk udang betina yang mempunyai daya tetas telur tinggi hanya 5 ekor (66,8\%-100\%). Hal yang sama terjadi pada peneluran ketiga, pemijahan induk udang semakin menurun, hanya 2 ekor dengan daya tetas tinggi. Pada peneluran keempat, hanya
2 ekor yang dapat memberikan daya tetas telur walaupun rendah $(35,4 \%-36,5 \%)$, sementara pada peneluran kelima hampir semua pemijahan induk udang sudah berhenti (1 ekor dengan daya tetas telur 18,1\%).

Pada pembenihan kedua, induk udang windu yang memijah sebanyak 17 ekor dengan daya tetas telur bervariasi dan menurun pada pemijahan kedua (9 ekor). Penurunan daya tetas telur terlihat sebesar 17,35\%-35,0\% (3 ekor) dan $61,23 \%-89,20 \%$ (6 ekor). Daya tetas telur pada pemijahan ketiga nampaknya sudah sangat menurun, 51,9\%-54,5\% (2 ekor).

Adanya telur yang tidak menetas pada beberapa induk udang windu dapat disebabkan oleh ketidaktersediaan sperma dalam kantung thelicum pada saat pemijahan. Udang windu merupakan udang yang mempunyai sistem pemijahan tertutup, sehingga harus terjadi mating sebelum pemijahan. Pada saat mating tersebut udang jantan menyimpan sperma dalam thelicum. Di samping itu, rendahnya daya tetas telur dapat disebabkan oleh pengaruh lingkungan terutama suhu yang rendah dan adanya infeksi bakteri di permukaan dinding telur, sehingga menghambat penetasan. Diketahui bahwa pada media pemijahan, induk juga mengeluarkan faeces dengan jumlah bakteri yang besar, sehingga telur berpeluang terkontaminasi oleh bakteri pada saat penetasan telur.

Keterbatasan kemampuan induk udang untuk pemijahan berkali-kali nampaknya karena faktor nutrisi dan lingkungan, sehingga disarankan bahwa larva yang digunakan untuk produksi benih menggunakan hasil pemijahan pertama dan kedua dengan daya tetas telur yang masih tinggi (> 70\%). Dari 40 pasang induk yang digunakan pada pembenihan pertama, hanya 21 induk yang dapat menghasilkan benih/pasca larva (PL), sedangkan pada pembenihan kedua, dari 20 induk udang windu, hanya 14 induk yang dapat memproduksi benih.

Frekuensi pemijahan induk udang windu selama pembenihan pertama ternyata lebih tinggi bila dibandingkan dengan induk udang yang digunakan untuk pembenihan kedua. Pada pembenihan pertama sebanyak $18 \%$ dari induk udang windu yang digunakan tidak memijah, sedangkan yang mengalami pemijahan dengan frekuensi satu kali sebanyak $20 \%$. Sementara, induk udang dengan frekuensi pemijahan 2, 3, 4, dan 5 kali masing- 
Tabel 2. Hasil deteksi infeksi virus pada induk udang betina dan jantan udang windu P. monodon

Table 2. Result of virus detection on male and female of tiger shrimp broodstock, P. monodon

\begin{tabular}{|c|c|c|c|c|c|c|c|c|c|}
\hline \multicolumn{2}{|c|}{ Induk (Broodstock) } & \multirow{2}{*}{ WSSV } & \multirow{2}{*}{ IHHNV } & \multirow{2}{*}{ YHV } & \multirow{2}{*}{ MBV } & \multirow{2}{*}{ NHPB } & \multirow{2}{*}{ BP } & \multirow{2}{*}{ TSV } & \multirow{2}{*}{ IMNV } \\
\hline $\mathbf{I}$ & II & & & & & & & & \\
\hline 우-1 & 우-2 & - & - & - & - & - & - & - & - \\
\hline q-5 & q -3 & - & - & - & - & - & - & - & - \\
\hline$q-9$ & $q-4$ & - & - & - & - & - & - & - & - \\
\hline$q-11$ & $q-5$ & - & - & - & - & - & - & - & - \\
\hline ㅇ-13 & ㅇ-10 & - & - & - & - & - & - & - & - \\
\hline q-14 & $\uparrow-11$ & - & - & - & - & - & - & - & - \\
\hline q -15 & $q-12$ & - & - & - & - & - & - & - & - \\
\hline 아-17 & ㅇ-13 & - & - & - & - & - & - & - & - \\
\hline q -18 & ㅇ-14 & - & - & - & - & - & - & - & - \\
\hline ㅇ-19 & $q-15$ & - & - & - & - & - & - & - & - \\
\hline ㅇ-21 & ㅇ-16 & - & - & - & - & - & - & - & - \\
\hline q -22 & q -18 & - & - & - & - & - & - & - & - \\
\hline $9-23$ & q-19 & - & - & - & - & - & - & - & - \\
\hline 우-28 & & - & - & - & - & - & - & - & - \\
\hline ㅇ-30 & & - & - & - & - & - & - & - & - \\
\hline $9-32$ & & - & - & - & - & - & - & - & - \\
\hline ㅇ-37 & & - & - & - & - & - & - & - & - \\
\hline 우-39 & & - & - & - & - & - & - & - & - \\
\hline o -45 & & - & - & - & - & - & - & - & - \\
\hline q -46 & & - & - & - & - & - & - & - & - \\
\hline q-47 & & - & - & - & - & - & - & - & - \\
\hline 우-48 & & - & - & - & - & - & - & - & - \\
\hline ㅇ-49 & & - & - & - & - & - & - & - & - \\
\hline$\delta-1$ & $\delta-1$ & - & - & - & - & - & - & - & - \\
\hline$\delta-2$ & $0^{\pi}-2$ & - & - & - & - & - & - & - & - \\
\hline $0-3$ & $0-3$ & - & - & - & - & - & - & - & - \\
\hline $0^{\pi}-4$ & $0-4$ & - & - & - & - & - & - & - & - \\
\hline$\delta-5$ & $\delta-5$ & - & - & - & - & - & - & - & - \\
\hline$\delta-6$ & t -6 & - & - & - & - & - & - & - & - \\
\hline $0-7$ & $0^{\pi}-7$ & - & - & - & - & - & - & - & - \\
\hline$\delta-8$ & $0-8$ & - & - & - & - & - & - & - & - \\
\hline t -9 & $0^{\pi}-9$ & - & - & - & - & - & - & - & - \\
\hline đ-10 & $0-10$ & - & - & - & - & - & - & - & - \\
\hline
\end{tabular}

masing sebanyak $28 \%, 10 \%, 10 \%$, dan $8 \%$. Nampak, bahwa induk udang windu sebagian besar hanya mampu memijah dua kali selama pembenihan. Pada pembenihan kedua, frekuensi pemijahan induk udang windu satu kali sebesar $40 \%$, sedangkan pemijahan 2 dan 3 kali hanya sebanyak 30\% dan 15\% dan tidak memijah sebesar 15\% (Gambar 1). 
Tabel 3. Daya tetas (\%) telur induk udang windu, $P$. monodon yang dipijahkan

Table 3. Hatching rate (\%) of black tiger shrimp, P. monodon broodstock after spawned

\begin{tabular}{|c|c|c|c|c|c|c|c|c|c|}
\hline \multirow[t]{2}{*}{$\begin{array}{c}\text { Induk } \\
\text { Broodst ock } \\
\text { (I) }\end{array}$} & \multicolumn{5}{|c|}{$\begin{array}{c}\text { Daya tetas } \\
\text { Hatching rate } \\
\text { (\%) }\end{array}$} & \multirow[t]{2}{*}{$\begin{array}{l}\text { Induk } \\
\text { Broodst ock } \\
\text { (II) }\end{array}$} & \multicolumn{3}{|c|}{$\begin{array}{c}\text { Daya tetas } \\
\text { Hatching rate } \\
\text { (\%) }\end{array}$} \\
\hline & I & II & III & IV & v & & I & II & III \\
\hline q-1 & 63.7 & 24 & & & & $q-1$ & 67 & & \\
\hline ㅇ-3 & 85.17 & & & & & $q-2$ & 73.8 & & \\
\hline ㅇ-5 & 71 & 47.4 & 86.44 & 36.5 & & ㅇ-3 & 87.6 & 89.2 & \\
\hline ㅇ-6 & 16.1 & 0 & 0 & & & ㅇ-4 & 70.25 & 80.3 & 54.5 \\
\hline ๑-7 & 25.7 & 0 & & & & o-5 & 75.2 & & \\
\hline q. 9 & 55 & 15 & 7.35 & 0 & 0 & $q-7$ & 0 & & \\
\hline ㅇ-10 & 0 & 0 & & & & †-8 & 75.7 & & \\
\hline q-11 & 85 & & & & & $q-9$ & 75 & & \\
\hline q-12 & 0 & & & & & q-10 & 7.9 & 35 & \\
\hline ㅇ-13 & 100 & 7.9 & 55.6 & 0 & & ㅇ-11 & 0 & 83 & \\
\hline q-14 & 23.8 & 0 & & & & ㅇ-12 & 78.12 & 89 & \\
\hline ㅇ-15 & 94 & 73.85 & & & & $q-13$ & 89.2 & 17.35 & \\
\hline ㅇ-16 & 47.4 & 27 & & & & $q-14$ & 38.3 & 61.23 & 0 \\
\hline q-17 & 85 & 0 & & & & $q-15$ & 90.5 & 72.32 & 51.9 \\
\hline ㅇ-18 & 100 & 75.9 & 0 & & & $q-16$ & 59.35 & 22.9 & \\
\hline ㅇ-19 & 100 & 88 & 90.8 & 0 & 0 & q-18 & 72.8 & & \\
\hline q-20 & 50.84 & 40.6 & & & & †-19 & 61.7 & & \\
\hline q-21 & 65 & 100 & 0 & & & & & & \\
\hline q-22 & 100 & 0 & & & & & & & \\
\hline ㅇ-23 & 81.6 & & & & & & & & \\
\hline$q-24$ & 33.7 & 0 & 35.83 & 35.4 & 18.1 & & & & \\
\hline$q-26$ & 0 & & & & & & & & \\
\hline ㅇ-27 & 100 & 0 & & & & & & & \\
\hline q-28 & 60 & 31 & 0 & 0 & & & & & \\
\hline q-30 & 60 & & & & & & & & \\
\hline ㅇ-31 & 18 & & & & & & & & \\
\hline o-32 & 71 & 48 & & & & & & & \\
\hline q-33 & 49 & & & & & & & & \\
\hline q-37 & 100 & 22.7 & 10.5 & 0 & 0 & & & & \\
\hline ㅇ-39 & 1.2 & 46 & 0 & 0 & & & & & \\
\hline q-41 & 3.5 & 0 & & & & & & & \\
\hline q-43 & 0 & & & & & & & & \\
\hline q-44 & 0 & & & & & & & & \\
\hline q -45 & 82.3 & 49.4 & & & & & & & \\
\hline q-46 & 95.5 & 0 & 0 & & & & & & \\
\hline ㅇ-47 & 74.66 & 0 & 0 & & & & & & \\
\hline ㅇ-48 & 38.8 & 66.8 & 74.6 & 0 & & & & & \\
\hline †-49 & 58.7 & 0 & & & & & & & \\
\hline
\end{tabular}



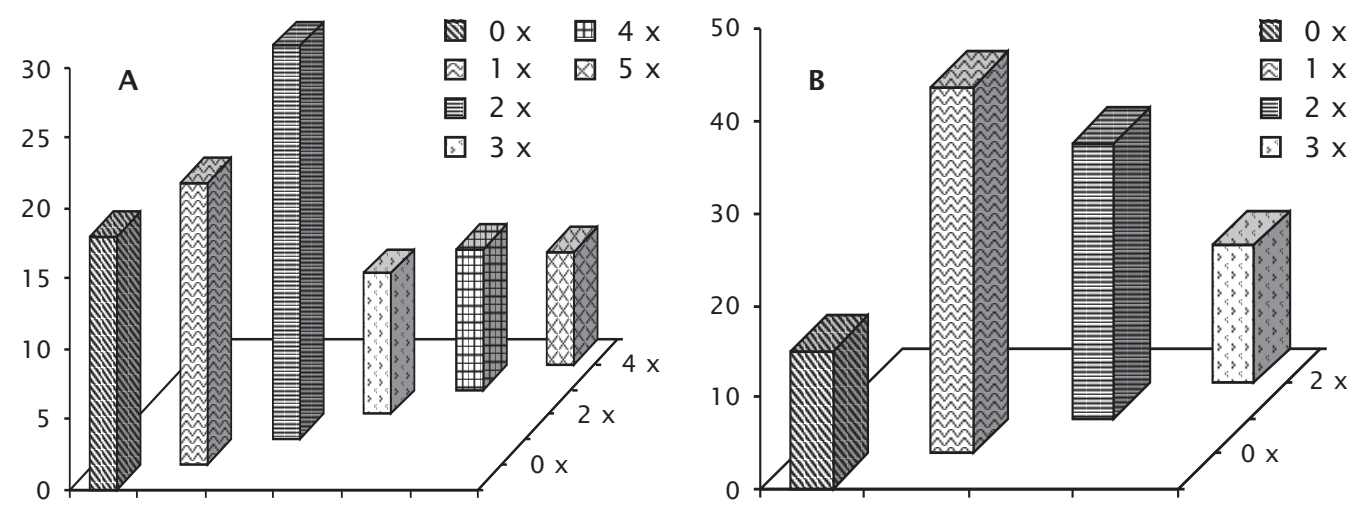

Gambar 1. Frekuensi pemijahan induk udang windu P. monodon yang digunakan untuk produksi benih (A) periode I dan (B) periode II

Figure 1. Spawning frequency of black tiger shrimp P. monodon broodstock that used to seed production (A) first period and (B) second period

Bila dilihat dari sintasan, nampak ada variasi sintasan hingga stadia PL-9. Larva udang windu yang dipelihara tercampur dari beberapa induk, menunjukkan sintasan yang relatif rendah bila dibandingkan dengan larva yang dipelihara per famili, walaupun ada beberapa famili yang memperoleh sintasan rendah. Selama pemeliharaan larva, digunakan probiotik yang ditujukan untuk mencegah terjadinya infeksi bakteri Vibrio (luminous vibriosis/kunangkunang). Infeksi vibriosis tersebut sangat sering terjadi selama pembenihan terutama pada pemeliharaan larva udang. Probiotik juga disinyalir dapat memacu pertumbuhan, meningkatkan sistem kekebalan benih dan mengkondusifkan kondisi lingkungan pemeliharaan udang.

Pada udang windu $P$. monodon, pertumbuhan, dan sintasan post larva (PL) menjadi lebih tinggi dengan pemberian bakteri heterotrofik (Pseudomonas sp. dan Micrococcus sp.) sebagai pengganti diatom sebesar $50 \%$ (Sunilkumar, 1995). Hasil pada udang $L$. vannamei juga telah dicobakan empat jenis probiotik dan diuji tantang $V$. parahaemoliticus menunjukkan peningkatan ketahanan tubuh dan sintasan (Balcazar et al., 2007) (Tabel 4).

\section{Penggunaan Gen Penyandi Tumbuh Cepat pada Benih F-1 Udang Windu $P$. monodon}

Hasil yang diperoleh dari analisis mikrosatelit dengan locus PmMS-1 1 A nampak bahwa separasi gen lebih baik dan akurat, yaitu diindikasikan dengan polimorfisme fragment
DNA pada 144 bp, yang merupakan gen penyandi tumbuh cepat. Sebanyak $60 \%$ benih ukuran besar dapat terekspresi pada level tersebut, sedangkan pada benih ukuran sedang dan kecil masing-masing hanya sebesar $20 \%$. Hal ini dapat dikatakan bahwa ada akurasi prediksi fenotip dari hasil polimorfisme. Nampaknya primer PmMS-1 1 A dapat dijadikan kuantitatif locus yang membawa sifat tumbuh cepat. Fragment DNA dengan berat molekul 149-150 bp sangat sulit untuk dijadikan penciri, karena hampir semua gen terekspresi pada kedua berat molekul tersebut. Menurut Xu et al. (1999), menyatakan bahwa kemelimpahan dan informasi alami mikrosatelit pada $P$. monodon dan potensialitasnya untuk amplifikasi cross-species menjadikan studi genetik lebih berguna.

Aplikasi gen penyandi ini pada benih F-1 udang windu dengan menggunakan agarose elektroforesis nampaknya sulit untuk mendeferensiasi gen tumbuh cepat oleh karena separasi yang terbatas (Gambar 2). Nampak bahwa perbedaan fragment DNA antara penyandi 144 bp dengan 149-150 bp sangat sulit, sehingga penentuan bahwa benih F-1 yang mempunyai atau tidak mempunyai gen pengontrol tumbuh cepat relatif tidak jelas. Pada Gambar 2 terlihat bahwa performasi pita DNA hasil amplifikasi PCR dengan locus PmMS11 A terlihat hampir sama $144 \mathrm{bp}$.

Hasil analisis mikrosatelit pada locus Pm MS-11 A, nampaknya dapat dijadikan indikator locus untuk sifat tumbuh cepat. Atas pertimbangan hasil tersebut, maka analisis 
Tabel 4. Sintasan benih udang windu, $P$. monodon pada kegiatan pembenihan

Table 4. Survival rate of black tiger shrimp, P. monodon fry on seed production

\begin{tabular}{|c|c|c|c|c|}
\hline \multirow{2}{*}{$\begin{array}{c}\text { Induk } \\
\text { Broodst ock }\end{array}$} & \multicolumn{4}{|c|}{ Sint asan (Survival rate) (\%) } \\
\hline & PL-1 & PL-9 & PL-1 & PL-9 \\
\hline \multicolumn{5}{|l|}{ I } \\
\hline q-46 & 40.6 & 15.4 & & \\
\hline ㅇ-13 & 42.4 & 13.2 & & \\
\hline$q-18$ & 94.0 & 86.1 & & \\
\hline$q-19$ & 50.2 & 40.8 & & \\
\hline q-9 & 52.0 & 5.5 & & \\
\hline $9-28$ & 24.0 & 80.0 & & \\
\hline$q-30$ & 13.6 & 100.0 & & \\
\hline †-22 & 79.0 & 42.8 & & \\
\hline o -5 & 13.6 & 1.4 & & \\
\hline$q-17$ & 57.2 & 29.2 & & \\
\hline †-21 & 34.5 & 3.4 & & \\
\hline $9-37 ; 47$ & 44.7 & 14.2 & & \\
\hline$q-14 ; 11 ; 33 ; 48$ & 19.9 & 35.4 & & \\
\hline १-19;49;18; 37 & 14.4 & 2.4 & & \\
\hline q-13; 19;21;39; 48 & 21.0 & 8.3 & & \\
\hline \multicolumn{5}{|l|}{ II } \\
\hline$q-2$ & & & 48.7 & 15.4 \\
\hline +-3 & & & 54.6 & 57.1 \\
\hline$q-4$ & & & 25.3 & 49.1 \\
\hline$q-5$ & & & 48.8 & 9.0 \\
\hline$q-12$ & & & 33.5 & 34.4 \\
\hline q-14 & & & 32.9 & 75.6 \\
\hline$q-15$ & & & 29.0 & 62.2 \\
\hline$q-16$ & & & 20.5 & 51.4 \\
\hline q-18 & & & 22.4 & 18.0 \\
\hline १-4; 14 & & & 52.9 & 77.4 \\
\hline q-10;12; 13 & & & 55.6 & 24.6 \\
\hline ㅇ-11;19 & & & 17.0 & 42.1 \\
\hline
\end{tabular}

dilanjutkan dengan menggunakan metoda SSCP agar dalam aplikasi seleksi dapat dilaksanakan secara cepat. Hasil yang diperoleh menunjukkan bahwa fragment DNA pada 144 bp pada induk jantan, betina, dan benih F-1 udang yang dianalisis, dapat terekspresi pita gen yang disinyalir mengontrol tumbuh cepat (Gambar 3).

Dari 40 ekor induk jantan yang dianalisis terlihat bahwa $45 \%$ tidak menunjukkan frag- ment DNA 144 bp. Dibandingkan dengan hasil analisis terhadap 42 ekor induk betina, terlihat bahwa hanya $21 \%$ tidak mengekspresikan gen tumbuh cepat. Metode SSCP dapat memberikan gambaran yang mendekati kesesuaian dengan hasil analisis menggunakan marker mikrosatelit dan sequensing. Besarnya hasil ekspresi gen penyandi tumbuh cepat berhubungan dengan jumlah sampel udang yang relatif banyak, sehingga kesalahan dalam ekspresi dapat diperkecil. 
A

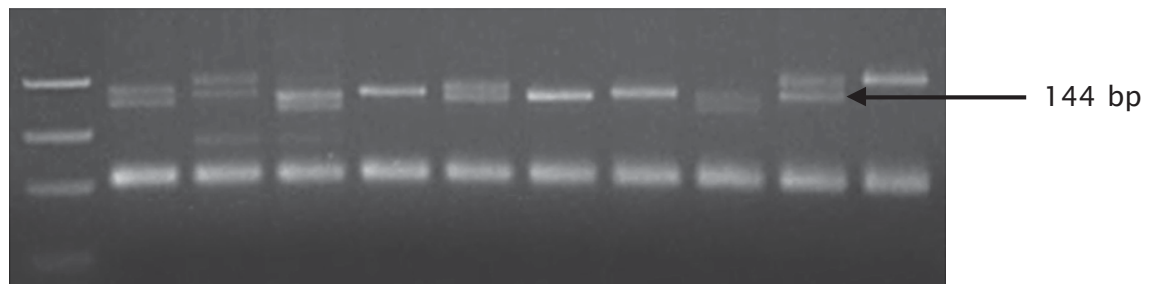

B

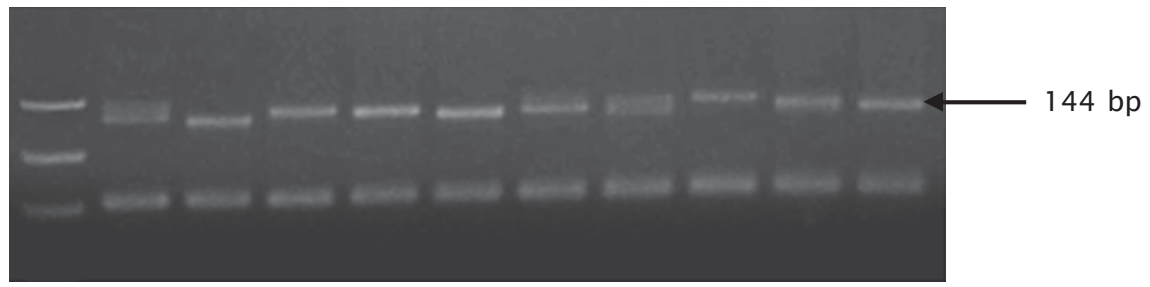

C

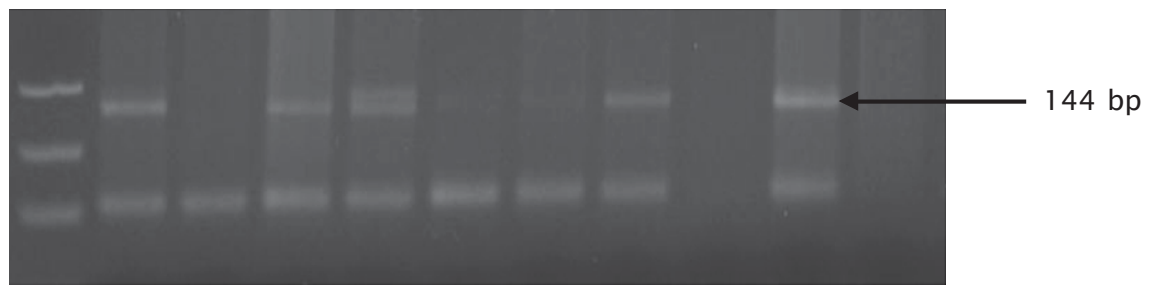

Gambar 2. Pola pita DNA melalui amplifikasi PCR dengan menggunakan locus mikrosatelit PmMS-1 1 A untuk aplikasi gen penyandi tumbuh cepat pada induk jantan (A), induk betina (B), dan benih F-1 (C) udang windu, $P$. monodon

Figure 2. Band pattern of DNA with PCR amplification use microsatelite locus of PmMS-1 1 A to applied of fast growth marker gen on male (A), female (B), broodstock and fry $(C)$ of black tiger shrimp, P. monodon

Hasil pengamatan terhadap benih F-1 udang windu menunjukkan bahwa 21 populasi benih (pembenihan I) dan 14 populasi benih (pembenihan II), dapat mengekspesikan fragment DNA yang merupakan allel tumbuh cepat dengan analisis kuantitatif locus PmMS-11 A. Benih yang dapat mengekspresikan fragment DNA 144 bp dijadikan benih tumbuh cepat untuk ditebar di tambak. Sementara, pada benih yang tidak mempunyai fragment tumbuh cepat dijadikan populasi kontrol. Benih F-1 yang terdeteksi tumbuh cepat adalah benih yang berasal dari induk betina 13,18 , $19,46,28,30,17,22$, dan benih campuran dari induk 19-37-49 (pembenihan I). Pada pembenihan II, benih F-1 yang teridentifikasi membawa gen pengontrol pertumbuhan adalah benih yang berasal dari induk betina $2,3,4,12,15,16,18$, dan benih campuran 1012-13.

Benih udang kontrol dalam penelitian ini merupakan benih yang tidak mengekspresikan fragment DNA 144 bp dan terdapat pada turunan F-1 dari induk 14-48, 11-33, 21-39 (pembenihan I) dan pada pembenihan II, benih kontrol terdapat pada turunan F-1 dari induk betina $5,11,14,19$.

Menurut Gupta et al. (2002), menyatakan bahwa gen penanda yang mengendalikan suatu karakter akan sangat membantu dalam efektivitas dan efisiensi proses seleksi, sehingga produk dan waktu seleksi dapat lebih valid dan singkat. Ekspresi karakter fenotip sangat ditentukan oleh faktor genetik dan lingkungan atau interaksi keduanya, sedangkan ekspresi genotip diindikasikan dari keragaman dan polimorfisme gen pada tiap individu atau populasi.

Pada dasarnya SSCP adalah metode analisis molekuler untuk menentukan perbedaan fragmentasi dan jumlah pasangan basa antar fragment gen dan masing-masing memisahkan 6-8 pasangan basa. (Kukita et al., 1997). Dengan demikian, penggunaan SSCP dapat 

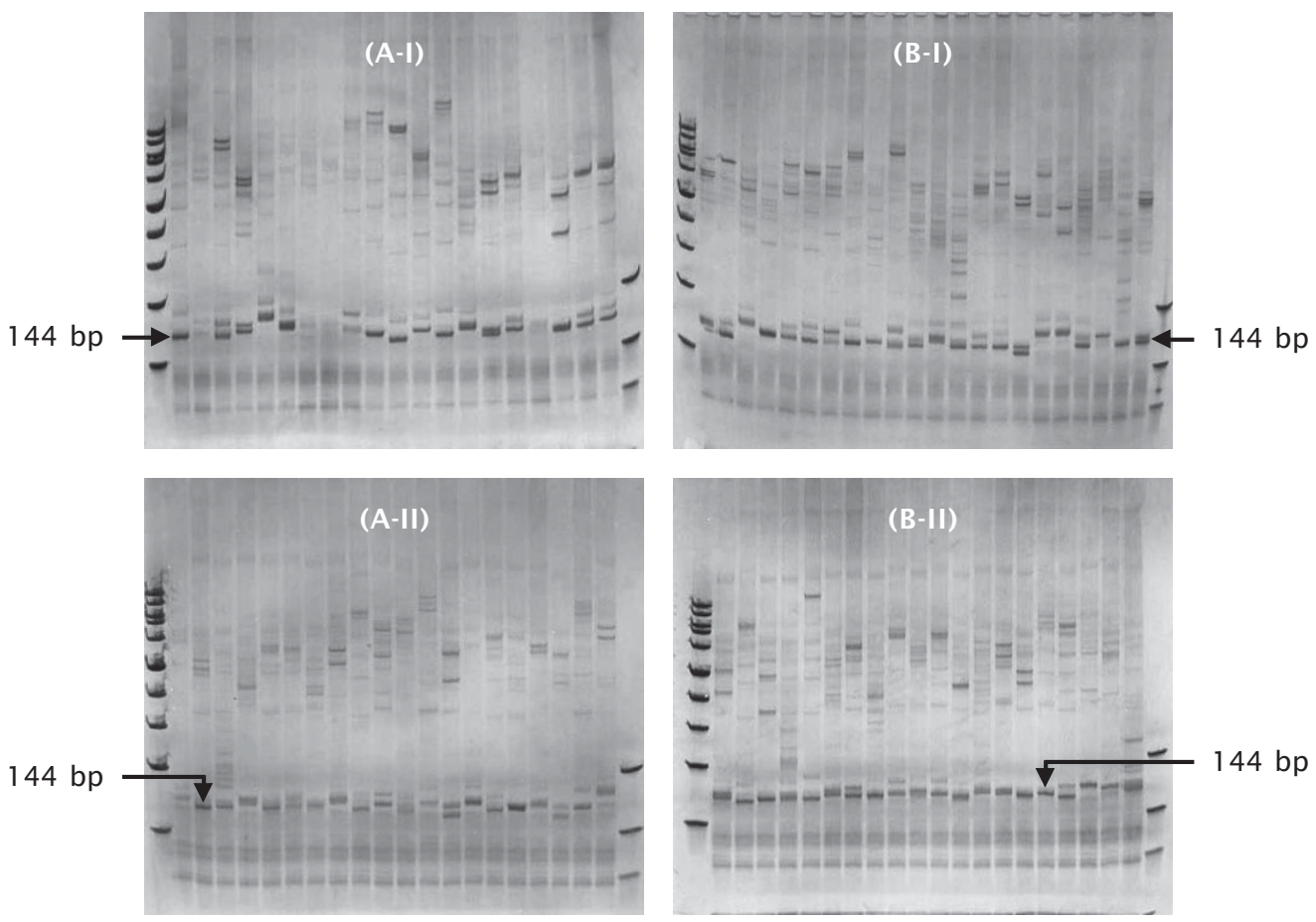

Gambar 3. Pola pita DNA induk jantan (AI-II) dan betina (B I-II) udang windu, P. monodon melalui metode SSCP dengan menggunakan locus PmMS-1 1 A sebagai locus indikator tumbuh cepat

Figure 3. DNA pattern of male and female of black tiger, P. monodon shrimp broodstock used SSCP method with PMMS-1 1 A locus as indicator of fast growth

memberikan polimorfisme DNA dan variasi urutan gen spesifik dapat dipisahkan serta lebih sensitif (Sunnucks et al., 2000).

Benih yang diperoleh dalam dua kali pembenihan menunjukkan bahwa benih udang yang dipelihara per famili mempunyai karakter fenotip yang sepintas tidak berbeda (Tabel 5). Pada stadia PL 12-15, benih F-1 yang dihasilkan masih relatif seragam ukurannya. Sementara, pada produk benih udang yang dipelihara dari populasi campuran, menunjukkan performansi fenotip yang lebih kecil. Hal ini juga tidak menutup kemungkinan adanya seks segregasi pada benih tersebut, sehingga benih jantan yang secara fenotipik berukuran lebih kecil. Walaupun dari ekspresi gen tidak menunjukkan karakter tumbuh cepat.

Dalam pemeliharan larva hingga benih ada mortalitas, nampaknya akibat dari sifat kanibalisme benih udang pada saat terjadi moulting. Pemeliharaan larva udang hingga ukuran pascalarva juga memerlukan kecermatan, mengingat kondisi lingkungan pemeliharaan terkontrol yang berbeda dengan kondisi alamnya.

\section{KESIMPULAN DAN SARAN}

\section{Kesimpulan}

- Gen penyandi tumbuh cepat pada udang windu sebagai indikator seleksi diperoleh dengan metode mikrosatelit dan diekspresikan pada locus PmMS1 1-A dengan $144 \mathrm{bp}$.

- PmMS1 1-A dapat dijadikan locus untuk sifat tumbuh cepat dengan adanya keakuratan dari hasil analisis mikrosatelit, amplifikasi PCR, dan SSCP marker.

- Benih udang windu tumbuh cepat yang dihasilkan pada pembenihan pertama sebanyak 537.513 ekor dan kontrol 124.660 ekor. Pada pembenihan kedua, diperoleh benih tumbuh cepat sebanyak 300.508 ekor dan kontrol 47.866 ekor. 
A

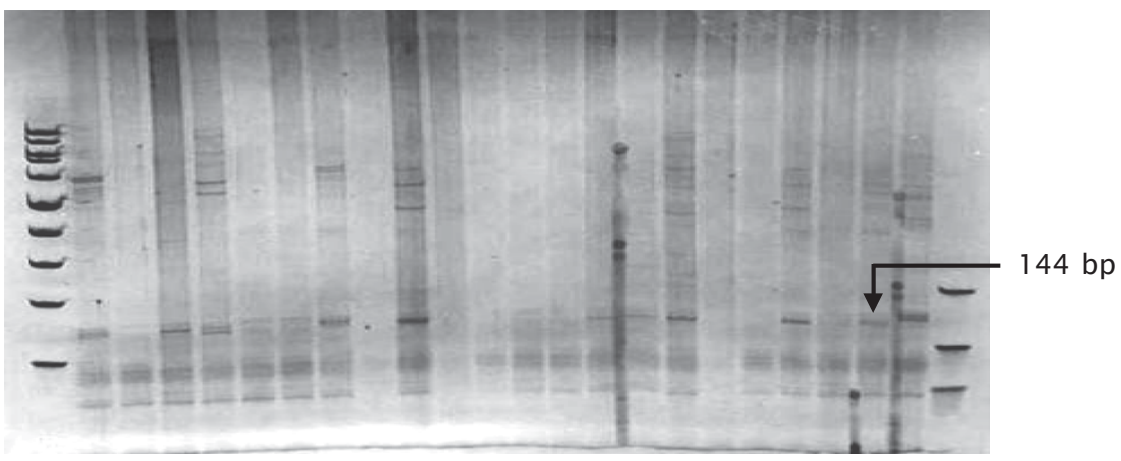

B

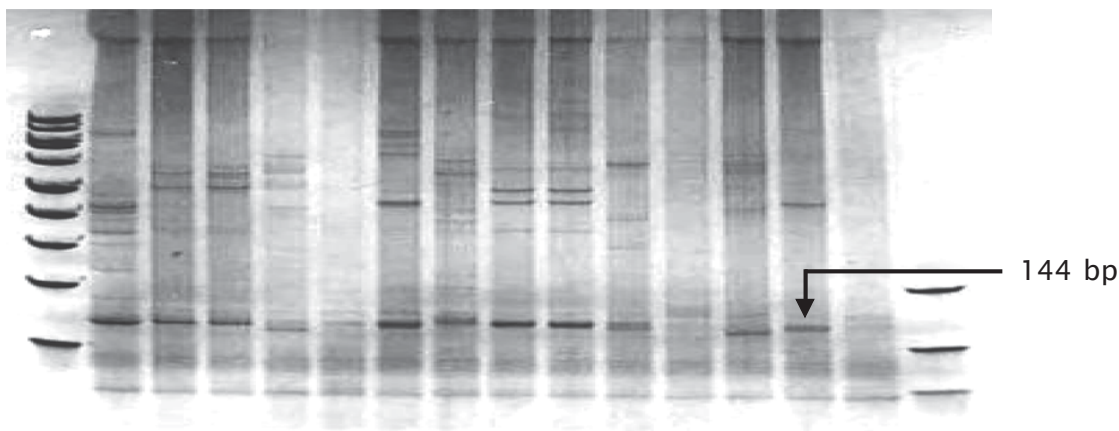

Gambar 4. Pola pita DNA benih F-1 dari pembenihan I (A) dan pembenihan kedua (B) udang windu $P$. monodon melalui metode SSCP dengan menggunakan locus PmMS-1 1 A sebagai locus indikator tumbuh cepat

Figure 4. DNA pattern of first generation fry of black tiger P. monodon shrimp used SSCP method with PMMS-1 1 A locus as indicator of fast growth

Tabel 5. Produk benih udang (PL-15) yang dihasilkan dari pembenihan udang windu, P. monodon Table 5. Shrimp fry product (PL-15) that produced in seed production of black tiger shrimp, $\boldsymbol{P}$. monodon

\begin{tabular}{|c|c|c|}
\hline $\begin{array}{c}\text { Induk } \\
\text { Broodstock }\end{array}$ & $\begin{array}{l}\text { Produk benih udang } \\
\text { Shrimp fry product } \\
\text { (ekor/pcs) (tail/pcs) }\end{array}$ & $\begin{array}{c}\text { Ket erangan } \\
\text { Remark }\end{array}$ \\
\hline \multicolumn{3}{|l|}{$\mathbf{I}$} \\
\hline 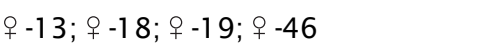 & 164,214 & Tumbuh cepat (Fast growth) \\
\hline q-28; + -30; + - 17 ; $q-22 ;$; $-19-37-49$ & 373,299 & Tumbuh cepat (Fast growth) \\
\hline ㅇ-14-48; 우-1 1-33; 우-21-39 & 124,660 & Kontrol (Control) \\
\hline Jumlah (Total) & 662,173 & \\
\hline \multicolumn{3}{|l|}{ II } \\
\hline 우-2; 우-3; 오-4; 우-12; 우-15; 우-16 & 110,716 & Tumbuh cepat (Fast growth) \\
\hline ㅇ -18; ㅇ-15; 우-3; ㅇ -10-13-12 & 189,792 & Tumbuh cepat (Fast growth) \\
\hline q -14; $q-5 ;$; $-11 ;$; -19 & 4,866 & Kontrol (Control) \\
\hline Jumlah (Total) & 348,374 & \\
\hline
\end{tabular}




\section{UCAPAN TERIMA KASIH}

Kepada rekan-rekan teknisi litkayasa kelompok Bioteknologi BBPPBL Gondol, diucapkan terima kasih sebesar-besarnya atas bantuan yang penuh tanggung jawab sehingga penelitian ini dapat terlaksana dengan baik.

\section{DAFTAR ACUAN}

Ditjen Perikanan Budidaya. 2009. Buku Saku Statistik Perikanan Budidaya Tahun 2009, DKP, Jakarta.

Argue, B.J., Arce, M., Lotz, J.M., \& Moss, S.M. 2002. Selective breeding of Pacific white shrimp (Litopenaeus vannamei) for growth and resistance to Taura Syndrome Virus. Aquaculture, 204: 447-460.

Balcazar, J.L., Rojas-Luna, T., \& Cunningham, D.P. 2007. Effect of the addition of four potential probiotic strains on the survival of pacific white shrimp (Litopenaeus vannamei) following immersion challenge with Vibrio parahaemolyticus. Journal of Invertebrate Pathology, 96(2): 147-150.

Benzie, J.A.H., Kenway, M., \& Trott, L. 1997. Estimates for The Heritability of Size in Juvenile $P$. monodon from Half-sib Mattings. Aquaculture, 152: 49-53.

Fjalestad, K.T., Can, W.C., Lotz, J., Sweeney, J.N., \& Gjedrem, T. 1999. Genetic variation and selection response in body weight and disease resistance in Pacific white shrimp (Penaus vannamei). Aquaculture, 173: 1019.

Gitterle, T., Rye, M., Salte, R., Cock, J., Johansen, H., Suarez, J.A., Lozano, C., \& Gjerde, B. 2005a. Genetic (co) variation in harvest body weight and survival in Penaeus (Litopenaeus) vannamei under standard commercial conditions. Aquaculture, 243: 83-92.

Gitterle, T., Salte, R., Gjerde, B., Cock, J., Johansen, H., Salazar, M., Lozano, C., \& Rye, M. 2005b. Genetic (co) variation Penaeus (Litopenaeus) vannamei. Aquaculture, 246: 139-149.

Gupta, P.K., Varshney, R.K., \& Prasad, M. 2002. Molecular Markers: Principles and Methodology. In: Jain, S.M., Brar, D.S., \& Ahloowalia,
B.S. (Eds.). Molecular Techniques in Crop Improvement, p. 9-54.

Haryanti, Permana, I G.N., Wardana, I.K., Muzaki, A., \& Fachrudin. 2006. Selektif breeding SPF (Specifik Pathogen Free) untuk udang windu, Penaeus, monodon F-1. Laporan Teknis Balai Besar Riset Perikanan Budidaya Laut Gondol, 11 hlm.

Haryanti, Fachrudin, Wardana, I.K., Permana, I G.N., Mahardika, K., \& Moria, S.B. 2012. Gen penciri tumbuh cepat sebagai indikator seleksi pada benih udang windu Penaeus monodon. J. Ris. Akuakultur, 7(2): 181-193.

Kukita, Y., Tahira, T., Sommer, S.S., \& Hayashi, K. 1997. SSCP Analysis of Long DNA Fragments in Low pH Gel. Human Mutation, (10): 400-407.

Rosenberry, R. 2000. World Shrimp farming 2000. Shrimp News Intl., p. 6-103.

Sunilkumar, M. 1995. Probiotics: an emerging concept in aquaculture nutrition and disease control. Sea Food Export (July 1995), p. 5-9.

Sunnucks, P., Wilson, A.C.C., Beheregaray, L.B., Zenger, K., French, J., \& Taylor, A.C. 2000. SSCP Is Not So Difficult: The Application and Utility of Single-Stranded Confirmation Polymorphism in Evolutionary Biology and Molecular Ecology. Molecular Ecology, (9): 1,699-1,710.

Wilson, K., Li, Y., Whan, V., Lehnert, S., Byrne, K., Moore, S., Pongsomboon, S., Tassanakayon, A., Rosenberg, G., Ballment, E., Fayazi, Z. Swan, J., Kenway, M., \& Benzie, J. 2002. Genetic mapping of the black tiger shrimp Penaeus monodon with Amplified Fragment Length Polymorphisme. Aquaculture, 204: 297-309.

Xu, Z., Primavera, J.H., de la Pena, L.D., Pettit, P., Belak, J., \& Alcívar-Waren, A. 2001. Genetic diversity of wild and cultured black tiger shrimp (Penaeus monodon) in the Philippines using microsatelite. Aquaculture, 199: 13-40.

Xu, Z., Dhar, A.K., Wyrzykowski, J., \& AlcivarWarren, A. 1999. Identification of abundant and informative microsatellites from shrimp (Penaeus monodon) genome. Animal Genetic, 30: 150-156. 